Egyptian Journal of Aquatic Biology \& Fisheries

Zoology Department, Faculty of Science,

Ain Shams University, Cairo, Egypt.

ISSN $1110-6131$

Vol. 25(2): 973 - 994 (2021)

www.ejabf.journals.ekb.eg

\title{
Tilapia Density-dependent Cowpea Production Potential in Aquaponics
}

\section{Prosun Roy ${ }^{1}$, Zubyda Mushtari Nadia ${ }^{1,2}$, M. Mosharraf Hossain ${ }^{1}$ and Md. Abdus Salam ${ }^{1^{*}}$}

${ }^{1}$ Department of Aquaculture, Bangladesh Agricultural University, Mymensingh 2202, Bangladesh

${ }^{2}$ Department of Aquatic Animal Health Management, Sher-e-Bangla Agricultural University, Dhaka 1207, Bangladesh

*Corresponding Author: salamaqua@bau.edu.bd

\section{ARTICLE INFO}

Article History:

Received: Sept. 5, 2020

Accepted: March 28, 2021

Online: April 30, 2021

Keywords:

Aquaponics,

Cowpea,

Fish density,

Production,

Water quality.

\section{INTRODUCTION}

Aquaponics is one of the most effective, water-efficient, self-fertilizing, and eco-friendly technologies for organic food production. In this system, plant nutrients instigate from the fish feed and fish waste. The objective of the current study was to assess and compare the plant growth and fish production in different fish stocking densities in aquaponics. Four different densities were tested for the study, such as 2.94 (T1), 3.92 (T2), 4.90 (T3), and 5.88 (T4) $\mathrm{kg} \mathrm{m}^{-}$ ${ }^{3}$ tilapia with an initial length of $16.8 \pm 0.17 \mathrm{~cm}$ and a weight of $72.6 \pm 5.14 \mathrm{~g}$, respectively. The tilapia were fed with commercial floating feed twice daily at $3 \%$ body weight. Sampling of fish and plant growth parameters were carried out fortnightly, whereas, water quality parameters such as temperature, dissolved oxygen, and $\mathrm{pH}$ were measured weekly, and electrical conductivity (EC), total dissolved solids (TDS), ammonia, nitrite, and nitrate were measured fortnightly. The data interpretation showed that $\mathrm{pH}$, ammonia, nitrite, EC, and TDS were significantly increased with the increasing fish densities. On the other hand, except $\mathrm{Zn}, \mathrm{Fe}$ and $\mathrm{Mn}$, all other nutrients of the fish tanks were significantly increased with the fish densities in the treatments. The first flower and pod appearance were observed in $\mathrm{T} 3$ at $39.33 \pm 4.03$ and $44.06 \pm 4.09$ days, respectively those were significantly the lowest with the fish density of $4.90 \mathrm{~kg}$ $\mathrm{m}^{-3}$. The highest and the lowest cowpea production were $4.61 \pm 0.88$ and $2.50 \pm 0.71 \mathrm{~kg} \mathrm{~m}^{-2}$ in $\mathrm{T} 3$ and $\mathrm{T} 4$, respectively. However, the highest fish production was $14.76 \pm 0.71 \mathrm{~kg} \mathrm{~m}^{-3}$ in $\mathrm{T} 4$, although $\mathrm{T} 3$ performed better in the case of other components, where most of the fish growth parameters were statistically similar among the treatments. Moreover, almost all the proximate compositions of cowpea and fish were statistically similar except that the moisture content in the tilapia and ash content in cowpea were significantly different. The study showed that the stocking density of the tilapia of $4.90 \mathrm{~kg} \mathrm{~m}^{-}$ ${ }^{3}$ resulted in higher production of cowpea by maintaining good water quality for the plant compared to the other stocking densities.

Aquaponics is an agro-aquaculture system integrating re-circulatory aquaculture system (RAS) with hydroponics. The system utilizes dissolved nutrients and solid wastes produced in the fish culture tanks, acting as source of organic fertilizer for the plants. 
Hence, the demand of aquaponics is increasing worldwide due to being a soilless system, eco-friendly, enhancing organic products, and having a sustainable nature (Love $\boldsymbol{e t}$ al., 2015; dos Santos, 2016; Junge et al., 2017). Considering the commercial as well as technological perspectives, the goal of this system is to maintain the suitable environment for fish and plant, removing toxic excreta, and other growth-inhibiting elements from the system (Endut $\boldsymbol{e t}$ al., 2016). In aquaponics, various inert media are used instead of soil as the base of plant and moisture retention in the root zone irrigating fish wastewater where plants serve as a bio-filter (Salam et al., 2014). The aquaponics mimics the natural ecosystem in combination of fish, plant, and microorganisms, where fish and plants are visible, but the microorganisms remain behind the scene. The fish metabolites and uneaten feed in the fish tank are the basis of nutrients in the system which contain dissolved nitrogen, calcium, phosphorus, sodium, boron, organic and inorganic compounds and other solids (Effendi et al., 2016; Delaide et al., 2017; Lennard \& Goddek, 2019).

The nutrients uptake by the plants depend on environmental factors such as air and water temperature in the plant root zone, level of nutrients in the water, $\mathrm{pH}$, plant growing phase, and the growth rate of the plants (Buzby \& Lin, 2014). Bacteria are involved in the nitrification process where toxic ammonia from fish waste is converted to nitrite and then to nitrate which is less toxic for fish (Wongkiew et al., 2017; Eck et al. 2019a). The nitrogen is taken up by plants in both the ammonium and nitrate form which it is controlled by nutrient concentrations and physiology of plants (Endut $\boldsymbol{e t}$ al., 2016; Maucieri et al., 2019a). The nitrates are rapidly absorbed by the roots without toxicity, whereas, higher ammonia have phytotoxic effects on plants. Excessive nitrogen supply enhances vegetative growth of plants and chlorophyll content in leaves; hence, it can result in low fruit yield and higher moisture content in the plant tissue (Maucieri $\boldsymbol{e t ~ a l . ,}$ 2019a). The nutrients uptake by the root in the soilless system vary with the water quality parameters such as $\mathrm{pH}$ and oxygen supply for nitrifying bacteria, electrical conductivity and synergy-antagonism of dissolved ions (Wortman, 2015; Eck et al., 2019a; Nadia et al., 2020). The nutrient absorption by the roots may be restricted when water $\mathrm{pH}$ is more than 7 due to precipitation of dissolved salts (Lennard \& Goddek, 2019; Maucieri $\boldsymbol{e t}$ al., 2019b). Physiology of plant depends on microbial activity in the root zone (Bartelme et al., 2018). Furthermore, it depends on the root morphology which is greatly influenced by nitrogen and phosphorus supply in the system (Razaq et al., 2017).

The performance of aquaponics as well as production of fish and plant directly depend on the balance of nutrients in the water which can be achieved by design and sizing of the system correctly (Buzby \& Lin, 2014; Somerville et al., 2014). The appropriate fish stocking density can provide suitable concentration of ammonium and nitrate nitrogen that are adequate for the successive plant growth (Endut $\boldsymbol{e t}$ al., 2016; Effendi et al., 2016) though the potassium, phosphorus, iron, and calcium levels are sometimes insufficient for maximum plants yield in aquaponics (Bittsanszky et al., 
2016; Schmautz et al., 2017). Large plant growing bed with few stocked fish may result in good water quality for the fish, but it will slower the plants vegetative growth and lessen total crop yield, whereas, small plant growing bed with higher stocking density of fish will result in excessive nutrients accumulation in the fish tank which is against the fish welfare (Somerville et al., 2014; Endut et al., 2016; Yildiz et al., 2017). But it is also important to consider that, the plants demand for macro and micronutrients depend on the fish species, fish and plant growth stage, season, and environmental conditions (Baxter, 2015; Nozzi et al., 2018; Maucieri, 2019a).

Fruit plants commonly grown in aquaponics are tomato (Yogev et al., 2016; Monsees et al., 2017; Yang \& Kim, 2020), eggplant (Ayipio et al., 2019), cucumber (Graber \& Junge, 2009), pepper (Wortman, 2015), strawberry (Somerville et al., 2014; Ayipio et al., 2019) and pumpkin (Oladimeji et al., 2018). The popular vegetable, cowpea (Vigna unguiculata L. Walp.) can be grown in aquaponics as it is a widely cultivated annual crop having low-nutrient requirements for its growth and fruit production. The cowpea grows well in a wide range of temperature $\left(18\right.$ to $\left.28^{\circ} \mathrm{C}\right)$, lowfertile soil, and has the ability to tolerate abiotic stress and a wide range of $\mathrm{pH}$ compared to other legumes (Badiane et al., 2014; Kebede \& Bekeko, 2020). Leguminous plants grow well in newly established aquaponics as it can fix nitrogen from the atmosphere (Somerville et al., 2014). The Nile tilapia (Oreochromis niloticus) is an omnivorous fish and extensively used in aquaponics (Love $\boldsymbol{e t}$ al., 2015; Wang $\boldsymbol{e t}$ al., 2016); because it can tolerate a wide range of environmental conditions and adapt well in aquaponics (Effendi et al., 2016; Makori et al., 2017; Nadia et al., 2020). There are few studies on aquaponics at different fish stocking densities with different vegetables (Hussain $\boldsymbol{e t}$ al., 2014; Goddek et al., 2015; Knaus \& Palm, 2017; Maucieri et al., 2019b), but aquaponics with the cowpea and the tilapia has not been studied yet. Consequently, the present study was aimed to test the effect of stocking tilapia in four different densities on the water quality, plant and fish growth, proximate composition of the tilapia, plant and cowpea production in aquaponics.

\section{MATERIALS AND METHODS}

\section{Experimental setup}

The experiment was carried out at the "BAU Aquaponics Oasis" Laboratory, Department of Aquaculture, Faculty of Fisheries, Bangladesh Agricultural University (BAU), Mymensingh from the $5^{\text {th }}$ of July to the $2^{\text {nd }}$ of October 2018. Each sub-system was mainly comprised of a fish holding tank $\left(0.74 \mathrm{~m}^{3}\right)$, a cowpea growing bed $\left(0.57 \mathrm{~m}^{2}\right)$, siphoning tube, irrigation pump and air pump. Media based aquaponics was chosen for this experiment where four treatments were used such as $2.94,3.92,4.90$ and $5.88 \mathrm{~kg} \mathrm{~m}^{-3}$ noted as $\mathrm{T} 1, \mathrm{~T} 2, \mathrm{~T} 3$ and $\mathrm{T} 4$, respectively with three replicates following randomized complete block design. 


\section{Cowpea sapling production}

Indian Institute of Vegetable Research, Varanasi developed a bush variety of cowpea (Lal et al., 2016) which is known as Kashi-Kanchan [Vigna unguiculata (L.) Walp.] and was used in the experiment. The seeds were sown 25 days before transplantation in the aquaponics. Initially, cowpea seeds were collected from Bangladesh Agricultural Research Institute (BARI), Gazipur, Bangladesh and soaked in water for an overnight. Then the seeds were placed in a tray filled with mixture of $50 \%$ coco-dust and $50 \%$ vermicompost. After spraying water, the tray was covered with a paper sheet. A week after seed germination, saplings were transferred into individual plastic disposable cup containing same ratio of coco-dust and vermicompost for hardening. It was done to reduce plant stress and stimulate adaptation mechanism which enhances the plant growth and productivity in the aquaponics (Masrufa et al., 2016).

\section{Bed preparation for cowpea cultivation}

Six cylindrical plastic drums were cut into two equal halves to make 12 cowpea beds for four treatments with triplicates. Before transplanting the saplings, the beds were cleaned with $\mathrm{KMnO}_{4}$ and watered and then sun dried. A hole was made underneath each container to make an outlet for draining the water to the fish tank. A T-stopper was also fitted in the hole of the grow beds to connect and control water flow. A perforated plastic standpipe was placed in one side of the bed for collecting irrigated water and draining easily to the fish tanks. Newly broken brick lets were sieved, washed, and put in the bed as media prior to plantation of saplings. Four to five liter water from an existing aquaponics was collected and sprayed on the brick lets in the newly set-up beds for seven days to initiate nitrifying bacterial growth following the procedure of Estim et al. (2018). Six cowpea saplings with average shoot height $(11.91 \pm 0.15 \mathrm{~cm})$ was planted in two rows in each bed. Number of plants per $\mathrm{m}^{2}$ was determined considering the guideline of Somerville et al. (2014) who recommended 4-8 plants per $\mathrm{m}^{2}$ for fruiting vegetables in aquaponics.

\section{Fish tank preparation}

After washing with $\mathrm{KMnO}_{4}$ and sun drying, the fish tanks were filled with $200 \mathrm{~L}$ clean underground water and kept for a week providing aeration. Juveniles of the Nile tilapia were collected and acclimatized for a week before stocking in separate tanks. After acclimatization, the tilapia having average weight of $72.56 \pm 4.25 \mathrm{~g}$ were released in $\mathrm{T} 1$, T2, T3 and T4 at 2.94, 3.92, 4.90 and $5.88 \mathrm{~kg} \mathrm{~m}^{-3}$ as initial stocking densities, respectively. The stocking density was maintained considering the minimum density to provide sufficient nitrogen for plant growth and maximum acceptable range for organic aquaculture (Maucieri et al., 2019b). 


\section{Fish rearing}

Imported commercial floating pelleted feed (Skretting, Neutreco International, Vietnam) was supplied manually twice daily (10 AM and 4 PM) at 3\% of the total fish biomass. A submergible water pump $(18 \mathrm{~W})$ was set in each tank to irrigate the water to the cowpea bed, and an air-pump ( $35 \mathrm{~W}$ ) having six nozzles was set to supply dissolved oxygen to three fish tanks with two nozzles with perforated stones in each tank. The water was irrigated from 9 am to $5 \mathrm{pm}$, and aeration was continued for $24 \mathrm{hr}$ throughout the experiment. There was no water replacement during the experimental period except adding lost water through evaporation every week. Moreover, solid wastes consisting of uneaten feed and fish waste were removed from the bottom of the tanks every day through siphoning.

\section{Growth performance and production of cowpea}

Shoot height measurement was started from plantation and measured fortnightly from the surface of media to the top of the main stem using a measuring tape. The height of the $1^{\text {st }}$ branch and the $1^{\text {st }}$ flower appearance in each plant were also recorded. Moreover, days for appearing the $1^{\text {st }}$ flower and pod after sowing were observed and recorded. Mature and market size cowpea pods were harvested regularly, and length and weight were recorded. At the end of the experiment, all the plants were pulled out from the beds and the length and weight of shoots and roots were measured and recorded. Weight of individual root was divided by individual shoot weight to get root-shoot ratio.

\section{Sampling and harvesting fish}

The length and weight of the tilapia were measured fortnightly with a measurement board and an electronic balance (AND EK 600i), respectively. The fish growth parameters such as length gain, percent length gain, weight gain, percent weight gain, specific growth rate (SGR), food conversion ratio (FCR), survival rate and production were calculated following the formula used by Moniruzzaman et al. (2015).

\section{Water quality parameters of fish tanks}

Water temperature, dissolved oxygen (DO) and $\mathrm{pH}$ were measured weekly using a laboratory thermometer, a Lutron Dissolved Oxygen meter PDO-519, and an Oakton EcoTestr ${ }^{\mathrm{TM}} \mathrm{pH} 2+$ Pocket $\mathrm{pH}$ Meter, respectively. Ammonia $\left(\mathrm{NH}_{3}\right)$, nitrite $\left(\mathrm{NO}_{2}\right)$ and nitrate $\left(\mathrm{NO}_{3}\right)$ were measured fortnightly using 'API Freshwater Master Test Kits, United States', where test kits and color strips were used to measure the value. Moreover, electrical conductivity (EC) and total dissolved solids (TDS) were also measured fortnightly with E-1 portable TDS and EC meter. Concentration of potassium (K), calcium $(\mathrm{Ca})$, magnesium $(\mathrm{Mg})$, boron $(\mathrm{B})$, copper $(\mathrm{Cu})$, sulfur $(\mathrm{S})$, phosphorus $(\mathrm{P})$, zinc $(\mathrm{Zn})$, iron $(\mathrm{Fe})$ and manganese $(\mathrm{Mn})$ in the fish tank water were measured twice, at the beginning and the end of the experiment. 


\section{Proximate composition determination}

Proximate composition of cowpea, fish, and fish feed (moisture, crude protein, crude lipid, crude fiber, ash and carbohydrate) were determined following AOAC (2019) method after finishing the trial.

\section{Data processing and analysis}

The data were statistically analyzed for variance and one-way ANOVA using SPSS 20.00 (Statistical Package for Social Sciences), and significant differences among the mean values of the treatments were compared using Duncan's Multiple Range Test (DMRT) considering 5 and $1 \%$ level of probability.

\section{RESULTS AND DISCUSSION}

\section{Water quality parameters}

The water temperature fluctuated throughout the study ranging from 26.33 to $32.00{ }^{\circ} \mathrm{C}$ (Fig. 1), and the mean values were statistically similar among the treatments in the present study (Table 1). Dissolved oxygen (DO) in T1, T2, T3 and T4 were $6.05 \pm 1.26,6.50 \pm 1.06,5.97 \pm 1.19$, and $5.81 \pm 1.06 \mathrm{mg} \mathrm{L}^{-1}$, respectively which was also statistically similar $(\mathrm{P}>0.05)$ among the treatments. The range of water temperature and DO were suitable for plant, fish, and micro-organisms in bio-filter during trial (Somerville et al., 2014; Maucieri et al., 2019b).

The highest mean $\mathrm{pH}$ value was recorded in $\mathrm{T} 4(7.94 \pm 0.27)$, and slightly alkaline $\mathrm{pH}$ was observed in all the treatments (ranging from 7.13 to 8.33) throughout the experimental period (Fig. 1\& Table 1). The $\mathrm{pH}$ values were significantly different among the treatments $(\mathrm{P}<0.05)$ and those were suitable for the tilapia and microbial population (Makori et al., 2017). But they were bit higher than the recommended range ( $\mathrm{pH}$ 5.5-7.5) for plant growth (Somerville et al., 2014). Effendi et al. (2016) reported $\mathrm{pH}$ value of 6.38-8.14 in aquaponics with the tilapia and romaine lettuce at fish stocking density of $3.12 \mathrm{~kg} \mathrm{~m}^{-3}$, and their findings was similar to the present findings.

The ammonia $\left(\mathrm{NH}_{3}\right)$ content in the fish tank water increased with the increasing fish density $(\mathrm{P} \leq 0.01)$, whereas the lowest and the highest concentration were found in $\mathrm{T} 1$ $\left(1.02 \pm 0.26 \mathrm{mg} \mathrm{L}^{-1}\right)$ and $\mathrm{T} 4\left(2.88 \pm 1.31 \mathrm{mg} \mathrm{L}^{-1}\right)$, respectively. Furthermore, $\mathrm{NO}_{2}$ concentration was also showed significant increment with the increasing fish biomass in the treatments $(\mathrm{P}<0.05)$ and the concentration in $\mathrm{T} 4$ was 56, 54 and $29 \%$ higher compared to $\mathrm{T} 1, \mathrm{~T} 2$ and $\mathrm{T} 3$, respectively (Table 1). $\mathrm{NO}_{3}$ values progressively increased with the fish density recording $17.14 \pm 6.36,20.00 \pm 8.16,23.10 \pm 10.95$ and $27.14 \pm 12.20$ mg L $\mathrm{L}^{-1}$ in T1, T2, T3 and T4, respectively. The highest values of $\mathrm{NH}_{3}, \mathrm{NO}_{2}$ and $\mathrm{NO}_{3}$ in T4 might be due to the higher organic matter produced and accumulated in the fish tanks including feed residues and feces. Moreover, $\mathrm{NH}_{3}$ and $\mathrm{NO}_{2}$ values were much higher than the values reported by Effendi et al. (2016) and Nozzi et al. (2018). The $\mathrm{NO}_{3}$ contents in the fish tank water were statistically similar among the treatments which might be due to 
the smoothly working bio-filtration and bacterial colony existing in the system. However, $\mathrm{NO}_{3}$ values in the present study were somehow lower than the those reported by Nozzi $\boldsymbol{e t}$ al. (2018) and Oladimeji et al. (2018). Remarkably, the present values of $\mathrm{NO}_{3}$ were higher than those of Effendi et al. (2016).
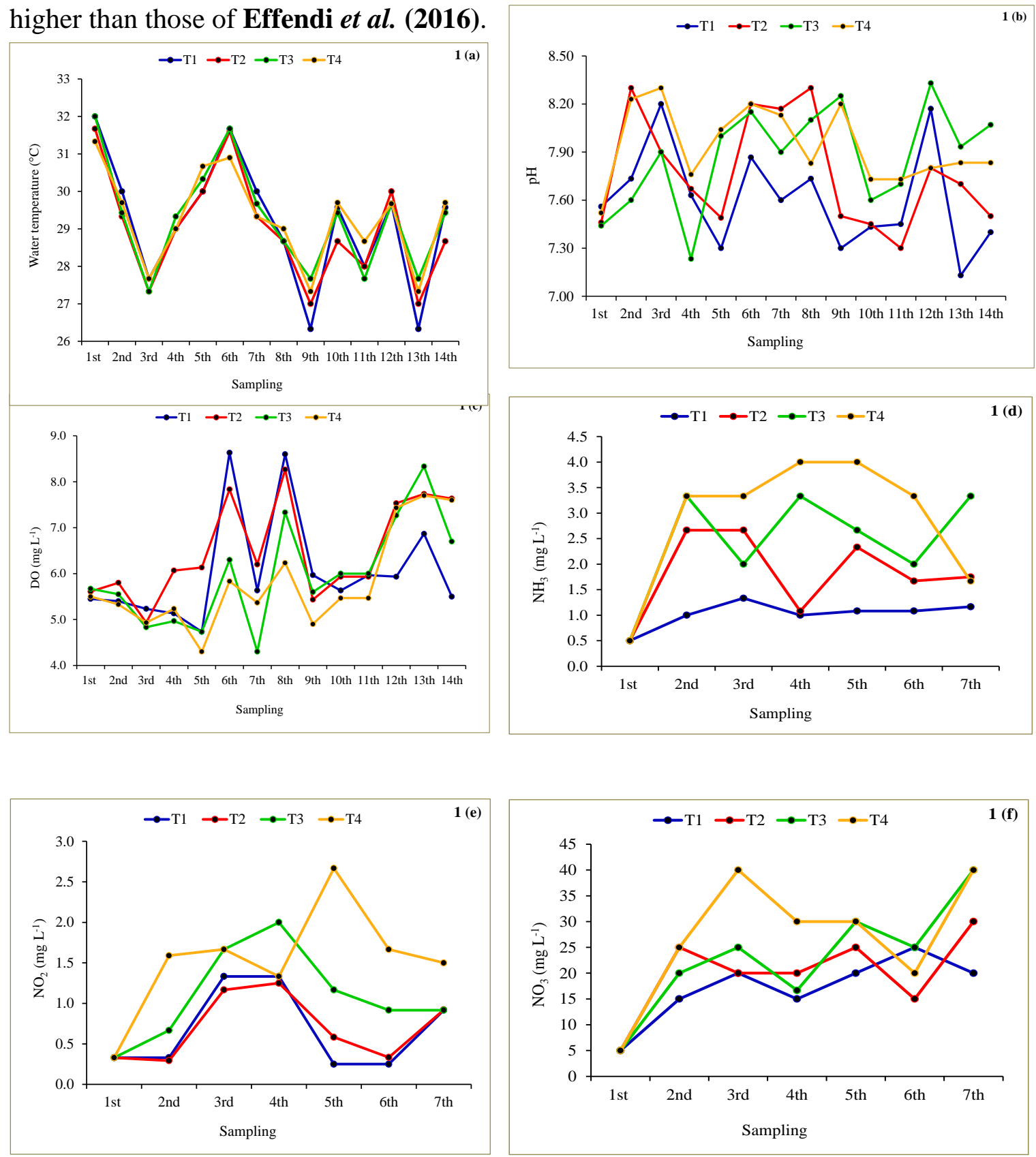

Fig. 1 (a) Water temperature (b) $\mathrm{pH}$ (c) $\mathrm{DO}$ (d) $\mathrm{NH}_{3}$ (e) $\mathrm{NO}_{2}$ and (f) $\mathrm{NO}_{3}$ concentrations in $\mathrm{T} 1, \mathrm{~T} 2, \mathrm{~T} 3$ and $\mathrm{T} 4$ throughout the experiment and symbols (dots) represent measured values on different sampling dates.

Here, T1, T2, T3 and T4 indicate 2.94, 3.92, 4.90 and $5.88 \mathrm{~kg} \mathrm{~m}^{-3}$ tilapia stocking densities, respectively. 
Table 1. Effect of the tilapia density on water temperature, $\mathrm{pH}, \mathrm{DO}, \mathrm{NH}_{3}, \mathrm{NO}_{2}, \mathrm{NO}_{3}$, TDS and EC in the fish tanks of aquaponics.

\begin{tabular}{|c|c|c|c|c|c|}
\hline Traits & $\mathbf{T 1}$ & $\mathbf{T} 2$ & T3 & T4 & $\begin{array}{l}\text { Signifi } \\
\text { cance }\end{array}$ \\
\hline $\begin{array}{l}\text { Water } \\
\text { temperature } \\
\left({ }^{\circ} \mathrm{C}\right)\end{array}$ & $29.18 \pm 1.69 a$ & $29.02 \pm 1.47 \mathrm{a}$ & $29.28 \pm 1.43 a$ & $29.29 \pm 1.25 \mathrm{a}$ & NS \\
\hline $\begin{array}{l}\mathrm{DO} \\
\left(\mathrm{mg} \mathrm{L}^{-1}\right)\end{array}$ & $6.05 \pm 1.26 \mathrm{a}$ & $6.50 \pm 1.06 \mathrm{a}$ & $5.97 \pm 1.19 \mathrm{a}$ & $5.81 \pm 1.06 \mathrm{a}$ & NS \\
\hline $\mathrm{pH}$ & $7.61 \pm 0.31 \mathrm{a}$ & $7.77 \pm 0.34 \mathrm{ab}$ & $7.89 \pm 0.31 b$ & $7.94 \pm 0.27 b$ & $*$ \\
\hline $\begin{array}{l}\mathrm{NH}_{3} \\
\left(\mathrm{mg} \mathrm{L}^{-1}\right)\end{array}$ & $1.02 \pm 0.26 \mathrm{a}$ & $1.81 \pm 0.82 \mathrm{ab}$ & $2.47 \pm 1.04 \mathrm{~b}$ & $2.88 \pm 1.31 b$ & $* *$ \\
\hline $\begin{array}{l}\mathrm{NO}_{2} \\
\left(\mathrm{mg} \mathrm{L}^{-1}\right)\end{array}$ & $0.67 \pm 0.49 a$ & $0.70 \pm 0.41 \mathrm{a}$ & $1.10 \pm 0.57 \mathrm{ab}$ & $1.54 \pm 0.69 b$ & $*$ \\
\hline $\begin{array}{l}\mathrm{NO}_{3} \\
\left(\mathrm{mg} \mathrm{L}^{-1}\right)\end{array}$ & $17.14 \pm 6.36 \mathrm{a}$ & $20.00 \pm 8.16 \mathrm{a}$ & $23.10 \pm 10.95 a$ & $\begin{array}{l}27.14 \pm 12.20 \\
\mathrm{a}\end{array}$ & NS \\
\hline $\begin{array}{l}\text { TDS } \\
\left(\mathrm{mg} \mathrm{L}^{-1}\right)\end{array}$ & $\begin{array}{l}188.36 \pm 36.4 \\
5 a\end{array}$ & $\begin{array}{l}202.46 \pm 39.0 \\
9 \mathrm{ab}\end{array}$ & $\begin{array}{l}228.57 \pm 47.87 \\
\text { bc }\end{array}$ & $\begin{array}{l}249.51 \pm 57.1 \\
2 c\end{array}$ & $* *$ \\
\hline $\begin{array}{l}\text { EC } \\
\left(\mu \mathrm{scm}^{-1}\right)\end{array}$ & $\begin{array}{l}402.00 \pm 111 \\
14 \mathrm{a}\end{array}$ & $\begin{array}{l}407.25 \pm 100 \\
72 \mathrm{a}\end{array}$ & $\begin{array}{l}486.06 \pm 115.8 \\
6 b\end{array}$ & $\begin{array}{l}508.89 \pm 120 \\
15 b\end{array}$ & $*$ \\
\hline
\end{tabular}

Here, T1, T2, T3 and T4 indicate 2.94, 3.92, 4.90 and $5.88 \mathrm{~kg} \mathrm{~m}^{-3}$ tilapia stocking densities, respectively. Means $( \pm \mathrm{SD})$ were calculated from three replicates for each treatment. Bars with different letters are significantly different at $\mathrm{P} \leq 0.05$ applying Duncan's Multiple Range Test (DMRT) and same letters indicate non-significance where $\mathrm{P}>0.05$. * indicates significance at $\mathrm{P}<0.05$; ** indicates significance at $\mathrm{P} \leq 0.01$ and $\mathrm{NS}$ means non-significance.

Moreover, the fish densities significantly influenced TDS and EC contents $(\mathrm{P} \leq 0.01$ for TDS; $\mathrm{P}<0.05$ for EC) of fish tank water (Table 1). The EC values in the present study were lower than the findings of Nozzi $\boldsymbol{e t ~ a l . ~ ( 2 0 1 8 ) , ~ w h o ~ r e p o r t e d ~ E C ~ v a l u e s ~ o f ~ 7 6 0 - 1 0 4 2 ~}$ $\mu \mathrm{s} \mathrm{cm}^{-1}$ in aquaponics without any fertilizer supplementation. The lower EC values in the present study might be due to the continuous absorption of nutrients by the root system of cowpea. Moreover, the higher the densities, the higher anion and cation are combined in the fish tank water, as microbial population contributed to process the particulates and enhanced TDS concentrations (Bittsanszky et al., 2016).

Significant increase of $\mathrm{K}, \mathrm{Ca}, \mathrm{Mg}, \mathrm{B}, \mathrm{Cu}$ and $\mathrm{S}$ concentration was observed with the increasing fish densities in the fish tank water (Table 2). Moreover, $\mathrm{P}$ concentration in $\mathrm{T} 2$ was 51, 17 and 35\% higher compared to T1, T3 and T4, respectively. On the other hand, the concentration of $\mathrm{Zn}, \mathrm{Fe}$ and Mn were statistically similar among the treatments. 
Maucieri et al. (2019b) also reported significantly higher $\mathrm{P}, \mathrm{Mg}, \mathrm{K}, \mathrm{Na}, \mathrm{Ca}$ and $\mathrm{S}$ with the higher fish densities. The phosphorus is an important nutrient for vegetative growth of cowpea, root growth and yield (Karikari et al., 2015). Moreover, $\mathrm{K}, \mathrm{P}, \mathrm{Cu}, \mathrm{Zn}$ and $\mathrm{Fe}$ concentrations were close to the findings of Bittsanszky et al. (2016) in aquaponics, whereas, $\mathrm{Ca}, \mathrm{Mg}$ and $\mathrm{Mn}$ concentrations were lower than those of Bittsanszky $\boldsymbol{e t}$ al. (2016); Nozzi et al. (2018) and Maucieri et al. (2019b). Delaide et al. (2016) observed that, aquaponics water lacked $\mathrm{K}, \mathrm{P}, \mathrm{Fe}, \mathrm{Cu}, \mathrm{Zn}$ and $\mathrm{Mn}$, where the only source for $\mathrm{Mg}$, $\mathrm{Ca}, \mathrm{B}, \mathrm{Cu}$, and $\mathrm{S}$ was the aquaponics water.

Table 2. Effect of the tilapia density on $\mathrm{K}, \mathrm{Ca}, \mathrm{Mg}, \mathrm{B}, \mathrm{Cu}, \mathrm{S}, \mathrm{P}, \mathrm{Zn}, \mathrm{Fe}$ and $\mathrm{Mn}$ concentration in the fish tanks water.

\begin{tabular}{|c|c|c|c|c|c|}
\hline \multirow{2}{*}{ Traits } & \multicolumn{4}{|c|}{$\mathrm{mg} \mathrm{L}^{-1}$} & \multirow{2}{*}{ Significance } \\
\hline & T1 & $\mathbf{T} 2$ & T3 & T4 & \\
\hline $\mathrm{K}$ & $44.70 \pm 3.62 \mathrm{a}$ & $47.11 \pm 4.00 \mathrm{a}$ & $48.46 \pm 2.02 \mathrm{a}$ & $61.79 \pm 10.93 b$ & $*$ \\
\hline $\mathrm{Ca}$ & $11.00 \pm 0.92 \mathrm{a}$ & $12.26 \pm 0.91 \mathrm{a}$ & $14.98 \pm 1.11 b$ & $18.32 \pm 1.32 \mathrm{c}$ & $* *$ \\
\hline $\mathrm{Mg}$ & $6.33 \pm 0.18 a$ & $6.18 \pm 0.47 \mathrm{a}$ & $7.66 \pm 0.41 b$ & $8.13 \pm 0.39 b$ & $* *$ \\
\hline B & $0.21 \pm 0.03 a$ & $0.33 \pm 0.05 b$ & $0.40 \pm 0.08 b$ & $0.58 \pm 0.02 \mathrm{c}$ & $* *$ \\
\hline $\mathrm{Cu}$ & $0.04 \pm 0.02 \mathrm{a}$ & $0.03 \pm 0.02 \mathrm{a}$ & $0.09 \pm 0.03 b$ & $0.11 \pm 0.02 b$ & $* *$ \\
\hline$S$ & $9.36 \pm 0.30 b$ & $8.05 \pm 0.86 a$ & $11.62 \pm 0.58 \mathrm{c}$ & $12.08 \pm 0.24 \mathrm{c}$ & $* *$ \\
\hline $\mathrm{P}$ & $4.26 \pm 0.44 a$ & $8.77 \pm 2.13 \mathrm{c}$ & $7.25 \pm 1.46 b c$ & $5.68 \pm 0.55 a b$ & $*$ \\
\hline $\mathrm{Zn}$ & $0.12 \pm 0.02 \mathrm{a}$ & $0.18 \pm 0.06 \mathrm{a}$ & $0.13 \pm 0.02 \mathrm{a}$ & $0.14 \pm 0.04 a$ & $\mathrm{NS}$ \\
\hline $\mathrm{Fe}$ & $0.01 \pm 0.01 \mathrm{a}$ & $0.01 \pm 0.01 \mathrm{a}$ & $0.01 \pm 0.01 \mathrm{a}$ & $0.02 \pm 0.01 \mathrm{a}$ & NS \\
\hline $\mathrm{Mn}$ & $0.53 \pm 0.20 \mathrm{a}$ & $0.33 \pm 0.28 \mathrm{a}$ & $0.26 \pm 0.06 \mathrm{a}$ & $0.15 \pm 0.04 \mathrm{a}$ & NS \\
\hline
\end{tabular}

Here, T1, T2, T3 and T4 indicate 2.94, 3.92, 4.90 and $5.88 \mathrm{~kg} \mathrm{~m}^{-3}$ tilapia stocking densities, respectively. Means $( \pm \mathrm{SD})$ were calculated from three replicates for each treatment. Bars with different letters are significantly different at $\mathrm{P} \leq 0.05$ applying Duncan's Multiple Range Test (DMRT). Similar letters indicate non-significance where $\mathrm{P}>0.05$. * indicates significance at $\mathrm{P}<0.05$; ** indicates significance at $\mathrm{P} \leq 0.01$ and NS means non-significance.

\section{Cowpea plant growth performance and yield}

In the present study, the cowpea growth was observed up to last sampling and an increasing trend of shoot height was observed from lower (T1) to higher fish density (T4). The cowpea shoot height was significantly different $(\mathrm{P}<0.05)$ among the treatments at the $3^{\text {rd }}$, the $4^{\text {th }}$ and last sampling (Fig. 2). From the cowpea sowing date to the appearance of the $1^{\text {st }}$ flower and the $1^{\text {st }}$ pod and the number of pod picking per plant was significantly $(\mathrm{P} \leq 0.01)$ influenced by the fish densities (Table 3$)$. The pods per plant and cowpea production from each treatment was also significantly $(\mathrm{P}<0.05)$ increased with the increasing fish densities, whereas $\mathrm{T} 3$ showed the highest production. The cowpea production in T3 was 24, 17 and $42 \%$ higher than T1, T2 and T4, respectively. 


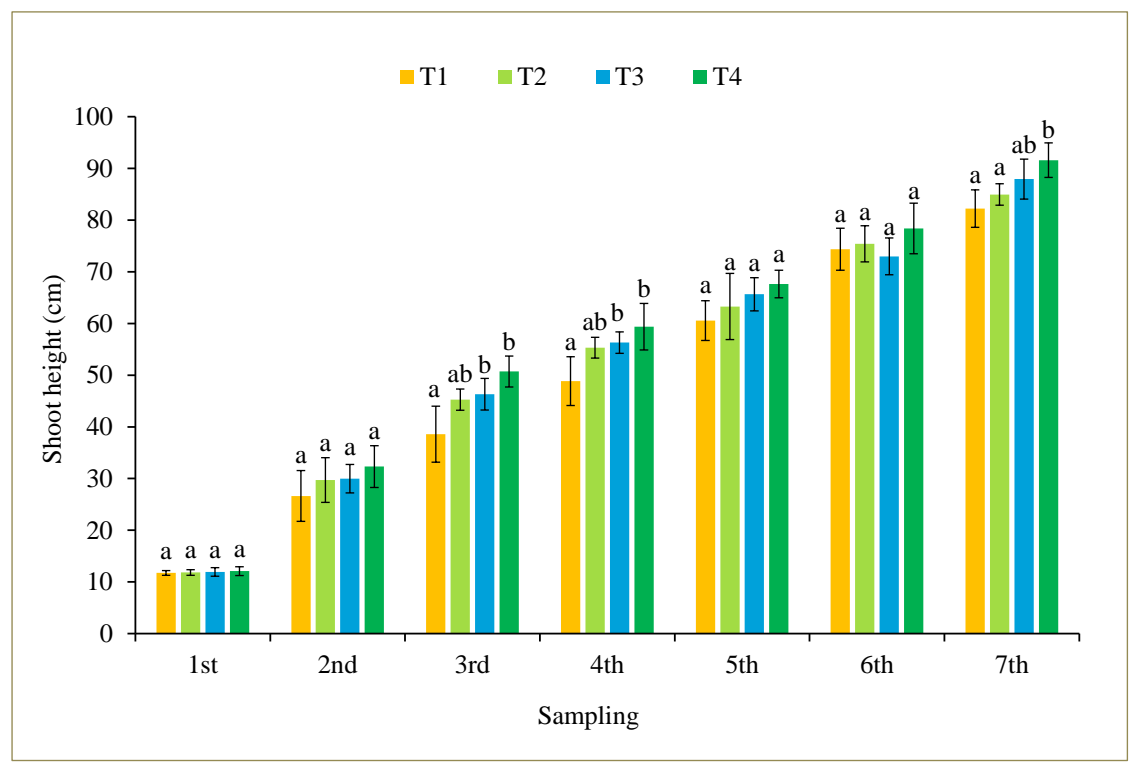

Fig. 2 Recorded shoot height at different sampling dates. Mean $( \pm \mathrm{SD})$ was calculated based on three replications of each treatment where, T1, T2, T3 and T4 indicate 2.94, $3.92,4.90$ and $5.88 \mathrm{~kg} \mathrm{~m}^{-3}$ stocking densities of the tilapia, respectively. Bars with different letters are significantly different at $\mathrm{P} \leq 0.05$ applying Duncan's Multiple Range Test (DMRT) and same letters indicate non-significance where $\mathrm{P}>0.05$.

The cowpea plant height changed depending on the cowpea variety, growth performances and duration of culture (Karikari et al., 2015). The root length of cowpea in T2 was 27, 2 and 18\% higher than T1, T3 and T4, respectively (Table 3). The higher P concentration in the present study might have contributed to root length that increased as $\mathrm{P}$ requires comparatively large quantities where metabolism and cell division are higher (Karikari et al., 2015). Dipikaben et al. (2018) reported final shoot height of $83.44 \mathrm{~cm}$ and production of $1.49 \mathrm{~kg} \mathrm{~m}^{-3}$ in 90 days of soil-grown cowpea (Kashi-Kanchan), however, $58 \%$ higher production was achieved in the present study $\left(3.51 \mathrm{~kg} \mathrm{~m}^{-3}\right.$ in 91 days). Moreover, Kyei-Boahen et al. (2017) reported 20.3-26.7 cowpea pod per plant after inoculating phosphorus fertilizer at different rates in soil based trial in consecutive two growing seasons. In the present study, T3 showed better nutrient combination for the commencement of flowers and pods, pod numbers, picking time and production than the other treatments. Somerville et al. (2014) stated that, excessive nitrates level results in delay of flowering in legume crops which is in the line with the present study findings. The $\mathrm{pH}$ value in $\mathrm{T} 4$ was more than 7.5 in all the samplings except for the $1^{\text {st }}$ sampling and the highest $\mathrm{pH}$ value might have resulted in nutrients imbalance and less production in the treatment than the other treatments (Soti et al., 2015). Wortman (2015) reported that, EC level of 500-1000 $\mu \mathrm{s} \mathrm{cm}^{-1}$ and slightly alkaline $\mathrm{pH}$ combinedly reduced the crop yield of leafy and fruity vegetables up to $76 \%$. Maucieri et al. (2019b) reported that, $2.50 \mathrm{~kg}$ $\mathrm{m}^{-3}$ European carp (Cyprinus carpio L.) stocking density influenced positively the water 
quality and achieved the best production of catalogna, lettuce and Swiss chard in aquaponics.

Table 3. Final shoot height, shoot weight, root length, root weight, root-shoot ratio, height of the $1^{\text {st }}$ branch, height of the $1^{\text {st }}$ flower, pod plant ${ }^{-1}$, picking plant ${ }^{-1}$, pod length, pod weight and cowpea production in the tilapia-based aquaponics.

\begin{tabular}{|c|c|c|c|c|c|}
\hline Traits & T1 & $\mathrm{T} 2$ & T3 & T4 & $\begin{array}{l}\text { Signif } \\
\text { cance }\end{array}$ \\
\hline $\begin{array}{l}\text { Final shoot } \\
\text { height }(\mathrm{cm})\end{array}$ & $82.21 \pm 3.62 \mathrm{a}$ & $84.95 \pm 2.08 \mathrm{a}$ & $87.93 \pm 3.86 a b$ & $91.57 \pm 3.34 b$ & $*$ \\
\hline $\begin{array}{l}\text { Shoot } \\
\text { weight (g) }\end{array}$ & $96.62 \pm 8.86 \mathrm{a}$ & $91.16 \pm 6.81 \mathrm{a}$ & $101.44 \pm 4.88 \mathrm{a}$ & $86.64 \pm 8.40 \mathrm{a}$ & NS \\
\hline $\begin{array}{l}\text { Root length } \\
(\mathrm{cm})\end{array}$ & $16.29 \pm 5.97 a$ & $22.46 \pm 6.90 \mathrm{~b}$ & $22.00 \pm 6.58 \mathrm{~b}$ & $18.48 \pm 7.17 \mathrm{ab}$ & $*$ \\
\hline $\begin{array}{l}\text { Root weight } \\
(\mathrm{g})\end{array}$ & $13.38 \pm 3.73 \mathrm{a}$ & $13.49 \pm 1.64 \mathrm{a}$ & $11.53 \pm 1.52 \mathrm{a}$ & $11.04 \pm 1.61 \mathrm{a}$ & NS \\
\hline $\begin{array}{l}\text { Root-shoot } \\
\text { ratio }\end{array}$ & $0.15 \pm 0.09 a$ & $0.16 \pm 0.05 a$ & $0.15 \pm 0.06 \mathrm{a}$ & $0.12 \pm 0.04 \mathrm{a}$ & NS \\
\hline $\begin{array}{l}\text { Height of } 1^{\text {st }} \\
\text { branch }\end{array}$ & $14.33 \pm 1.01 \mathrm{a}$ & $13.10 \pm 2.41 \mathrm{a}$ & $12.83 \pm 1.08 \mathrm{a}$ & $14.94 \pm 0.41 \mathrm{a}$ & NS \\
\hline $\begin{array}{l}\text { Height of } 1^{\text {st }} \\
\text { flower }\end{array}$ & $39.59 \pm 3.52 \mathrm{a}$ & $32.43 \pm 3.86 \mathrm{a}$ & $33.70 \pm 3.60 \mathrm{a}$ & $35.00 \pm 3.71 \mathrm{a}$ & NS \\
\hline $\begin{array}{l}\text { Days for } 1^{\text {st }} \\
\text { flower } \\
\text { appearance }\end{array}$ & $42.39 \pm 4.78 \mathrm{~b}$ & $41.50 \pm 4.11 \mathrm{ab}$ & $39.33 \pm 4.03 a$ & $45.56 \pm 3.60 \mathrm{c}$ & *** \\
\hline $\begin{array}{l}\text { Day for } 1^{\text {st }} \\
\text { pod } \\
\text { appearance }\end{array}$ & $46.50 \pm 4.11 \mathrm{ab}$ & $47.28 \pm 4.81 \mathrm{~b}$ & $44.06 \pm 4.09 \mathrm{a}$ & $51.44 \pm 4.00 \mathrm{c}$ & ** \\
\hline Pod plant $^{-1}$ & $40.27 \pm 6.18 \mathrm{ab}$ & $43.55 \pm 4.11 \mathrm{~b}$ & $47.34 \pm 5.30 \mathrm{~b}$ & $30.50 \pm 7.15 \mathrm{a}$ & * \\
\hline $\begin{array}{l}\text { Picking } \\
\text { plant }^{-1}\end{array}$ & $11.28 \pm 0.96 \mathrm{~b}$ & $11.83 \pm 0.73 b$ & $15.00 \pm 0.44 \mathrm{c}$ & $9.72 \pm 0.92 \mathrm{a}$ & ** \\
\hline $\begin{array}{l}\text { Pod length } \\
(\mathrm{cm})\end{array}$ & $22.06 \pm 0.64 \mathrm{a}$ & $22.44 \pm 1.11 \mathrm{a}$ & $22.40 \pm 0.66 \mathrm{a}$ & $21.96 \pm 0.92 \mathrm{a}$ & NS \\
\hline $\begin{array}{l}\text { Pod weight } \\
\text { (g) }\end{array}$ & $11.54 \pm 5.03 \mathrm{a}$ & $15.27 \pm 18.07 \mathrm{a}$ & $13.05 \pm 7.04 a$ & $10.87 \pm 3.12 \mathrm{a}$ & NS \\
\hline $\begin{array}{l}\text { Cowpea } \\
\text { production } \\
\left(\mathrm{kg} \mathrm{m}^{-2}\right)\end{array}$ & $3.32 \pm 0.53 \mathrm{ab}$ & $3.58 \pm 0.58 \mathrm{ab}$ & $4.61 \pm 0.88 \mathrm{~b}$ & $2.50 \pm 0.71 \mathrm{a}$ & $*$ \\
\hline
\end{tabular}

Here, T1, T2, T3 and T4 indicate 2.94, 3.92, 4.90 and $5.88 \mathrm{~kg} \mathrm{~m}^{-3}$ fish stocking densities, respectively. Means $( \pm \mathrm{SD})$ were calculated from three replicates for each 
treatment. Bars with different letters are significantly different at $\mathrm{P} \leq 0.05$ applying Duncan's Multiple Range Test (DMRT) and similar letters indicate non-significance where $\mathrm{P}>0.05$. * indicates significance at $\mathrm{P}<0.05 ; * *$ indicates significance at $\mathrm{P} \leq 0.01$ and NS means non-significance.

\section{Growth performance of tilapia and production}

Fish length and weight of the tilapia were fluctuated among the treatments throughout the experimental period (Fig. 3). Length gain, percent length gain, weight gain and FCR were statistically similar among the four treatments (Table 4). On the other hand, SGR were significantly reduced with the higher fish stocking densities $(\mathrm{P}<0.05)$, and the values were $1.17 \pm 0.04,1.14 \pm 0.08,1.07 \pm 0.05$, and $1.02 \pm 0.05 \% \mathrm{~d}^{-1}$ in $\mathrm{T} 1, \mathrm{~T} 2, \mathrm{~T} 3$ and T4, respectively. Moreover, the highest and the lowest survival rates were in T2 $(96.67 \pm 1.44 \%)$ and $\mathrm{T} 1(90.00 \pm 3.33 \%)$, respectively. However, fish production was almost double in T4 $(14.76 \pm 0.71 \%)$ than $\mathrm{T} 1(7.26 \pm 0.18 \%)$ which was significantly higher $(\mathrm{P} \leq 0.01)$ as well.

In the current study, the SGR of fish decreased with the increasing density of fish which might have been resulted from the competition for space and feed (Hussain $\boldsymbol{e t}$ al., 2014; Moniruzzaman et al., 2015; Maucieri et al., 2019b). The FCR in the present study were statistically similar among the treatments, a result which coincides with the findings of Qi et al. (2016). The survival of the tilapia (92 to 98\%) was not influenced by the increasing fish densities and the survival rate is similar to that of Salam et al. (2014). The tilapia stocked in aquaponics at $4.0 \mathrm{~kg} \mathrm{~m}^{-3}$ for 42 days showed similar fish survival rate $(93 \%)$ to the present study, but dissimilarity was detected with respect to the FCR (1.78 on average) (Effendi et al., 2016). In the contemporary study, the tilapia production increased with the increasing fish densities (T1 to T4), here the water quality did neither affect the fish production nor the survival rate. Moniruzzaman et al. (2015) reported similar result in cage culture of the tilapia, where production increased up to 0.76 to 1.52 $\mathrm{kg} \mathrm{m}^{-3}$ then declined at the stocking density of $1.90 \mathrm{~kg} \mathrm{~m}^{-3}$. Moreover, Maucieri et al. (2019b) also reported the highest tilapia production in the higher density regardless of higher $\mathrm{pH}, \mathrm{NH}_{3}, \mathrm{NO}_{2}$ and $\mathrm{NO}_{3}$ that might have been due to the buffering mechanism and symbiosis action in aquaponics. Mustapha and Atolagbe (2018) also reported higher survival of the tilapia fingerlings at $\mathrm{pH} 8.0$ compared to the lower $\mathrm{pH}$ (3.0 to 6.0) level. 


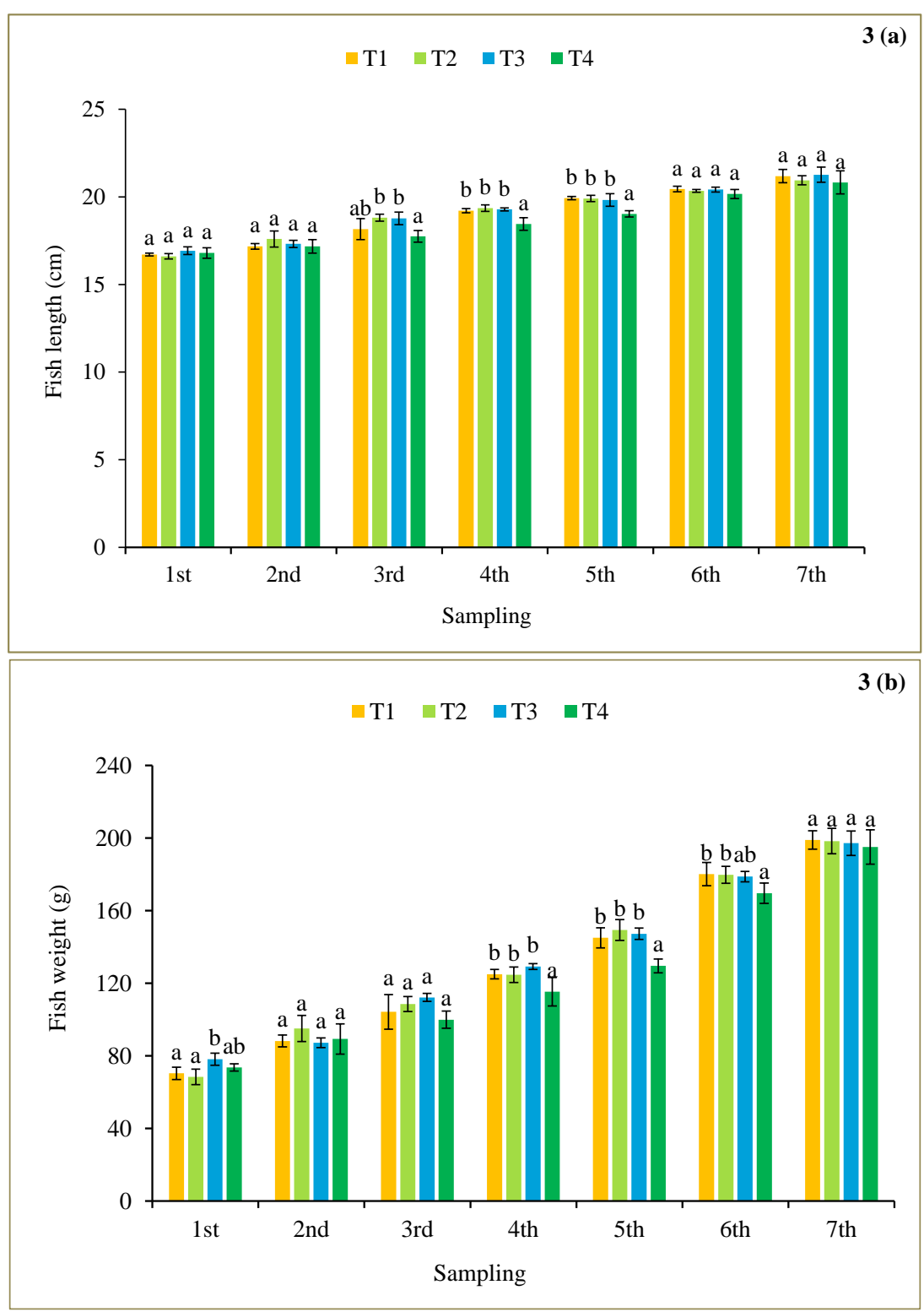

Fig. 3 (a) Length and (b) weight of tilapia at different sampling dates. Mean $( \pm \mathrm{SD})$ was calculated based on three replications of each treatment where, T1, T2, T3 and T4 indicate $2.94,3.92,4.90$ and $5.88 \mathrm{~kg} \mathrm{~m}^{-3}$ stocking densities of tilapia, respectively. Bars with different letters are significantly different at $\mathrm{P} \leq 0.05$ applying Duncan's Multiple Range Test (DMRT) and same letters indicate non-significance where $\mathrm{P}>0.05$.

\section{Proximate composition of cowpea and tilapia}

The proximate composition analysis of cowpea showed that only the ash content was significantly different $(\mathrm{P} \leq 0.01)$ among the treatments. In case of proximate composition of tilapia, only the moisture content in T2 $(74.99 \pm 0.61 \%)$ was significantly higher $(\mathrm{P} \leq 0.01)$ than the other treatments (Table 5\& Fig. 4), whereas, the supplied fish feed was the same in all the treatments in the study consisting of 12.24, 28.31, 6.88, 5.20, 
8.79 and $38.58 \%$ moisture, crude protein, crude lipid, crude fiber, ash and carbohydrate, respectively (Table 5).

Table 4. Growth performance of the tilapia produced in four different stocking densities in the aquaponics.

\begin{tabular}{|c|c|c|c|c|c|}
\hline Traits & $\mathbf{T 1}$ & $\mathbf{T} 2$ & T3 & $\mathbf{T 4}$ & $\begin{array}{l}\text { Signifi } \\
\text { cance }\end{array}$ \\
\hline $\begin{array}{l}\text { Length gain } \\
(\mathrm{cm})\end{array}$ & $4.34 \pm 0.12 \mathrm{a}$ & $4.48 \pm 0.43 \mathrm{a}$ & $4.33 \pm 0.62 \mathrm{a}$ & $4.03 \pm 0.56 a$ & NS \\
\hline $\begin{array}{l}\text { Percent length } \\
\text { gain }(\%)\end{array}$ & $26.13 \pm 0.52 \mathrm{a}$ & $26.84 \pm 2.65 a$ & $25.62 \pm 3.95 a$ & $24.01 \pm 3.26 \mathrm{a}$ & NS \\
\hline $\begin{array}{l}\text { Weight gain } \\
\text { (g) }\end{array}$ & $128.65 \pm 7.40 \mathrm{a}$ & $129.92 \pm 4.50 \mathrm{a}$ & $119.09 \pm 5.84 a$ & $121.51 \pm 8.42 \mathrm{a}$ & NS \\
\hline $\begin{array}{l}\text { Percent } \\
\text { weight gain } \\
(\%)\end{array}$ & $183.5 \pm 18.65 b$ & $190.58 \pm 12.20 \mathrm{~b}$ & $\begin{array}{l}152.77 \pm 10.06 \\
\mathrm{a}\end{array}$ & $\begin{array}{l}165.21 \pm 10.27 \\
\mathrm{ab}\end{array}$ & $*$ \\
\hline $\begin{array}{l}\text { Specific } \\
\text { growth rate } \\
\left(\% \mathrm{~d}^{-1}\right)\end{array}$ & $1.17 \pm 0.04 b$ & $1.14 \pm 0.08 b$ & $1.07 \pm 0.05 \mathrm{ab}$ & $1.02 \pm 0.05 \mathrm{a}$ & $*$ \\
\hline FCR & $1.94 \pm 0.55 \mathrm{a}$ & $2.01 \pm 0.76 \mathrm{a}$ & $2.26 \pm 0.86 a$ & $2.16 \pm 0.84 a$ & NS \\
\hline $\begin{array}{l}\text { Survival rate } \\
(\%)\end{array}$ & $90.00 \pm 3.33 \mathrm{a}$ & $96.67 \pm 1.44 \mathrm{a}$ & $93.33 \pm 1.15 \mathrm{a}$ & $92.78 \pm 4.20 \mathrm{a}$ & NS \\
\hline $\begin{array}{l}\text { Tilapia } \\
\text { production } \\
\left(\mathrm{kg} \mathrm{m}^{-3}\right)\end{array}$ & $7.26 \pm 0.18 a$ & $10.45 \pm 0.37 b$ & $12.52 \pm 0.43 c$ & $14.76 \pm 0.71 d$ & $* *$ \\
\hline
\end{tabular}

Here, T1, T2, T3 and T4 indicate 2.94, 3.92, 4.90 and $5.88 \mathrm{~kg} \mathrm{~m}^{-3}$ tilapia stocking densities, respectively. Means $( \pm \mathrm{SD})$ were calculated from three replicates for each treatment. Bars with different letters are significantly different at $\mathrm{P} \leq 0.05$ applying Duncan's Multiple Range Test (DMRT) and similar letters indicate non-significance where $\mathrm{P}>0.05$. * indicates significance at $\mathrm{P}<0.05 ; * *$ indicates significance at $\mathrm{P} \leq 0.01$ and NS means non-significance. 
Table 5. Mean moisture, crude protein, crude lipid, crude fiber, ash and carbohydrate content in cowpea, fish and feed in four treatments in the tilapia based aquaponics.

\begin{tabular}{|c|c|c|c|c|c|c|}
\hline \multirow{2}{*}{\multicolumn{2}{|c|}{$\begin{array}{c}\text { Nutrient } \\
\text { components }\end{array}$}} & \multicolumn{4}{|c|}{$\%$} & \multirow{2}{*}{$\begin{array}{l}\text { Signif } \\
\text { icance }\end{array}$} \\
\hline & & T1 & $\mathbf{T 2}$ & T3 & $\mathbf{T 4}$ & \\
\hline \multirow{3}{*}{ Moisture } & Cowpea & $84.50 \pm 0.95 a$ & $83.93 \pm 0.94 a$ & $83.96 \pm 0.59 a$ & $84.21 \pm 0.63 a$ & NS \\
\hline & Tilapia & $73.02 \pm 0.48 \mathrm{a}$ & $74.99 \pm 0.61 b$ & $73.03 \pm 0.88 \mathrm{a}$ & $73.57 \pm 0.58 \mathrm{a}$ & $* *$ \\
\hline & Feed & 12.24 & 12.24 & 12.24 & 12.24 & - \\
\hline \multirow{3}{*}{$\begin{array}{l}\text { Crude } \\
\text { protein }\end{array}$} & Cowpea & $2.17 \pm 0.07 \mathrm{a}$ & $2.15 \pm 0.06 \mathrm{a}$ & $2.05 \pm 0.12 \mathrm{a}$ & $2.07 \pm 0.08 \mathrm{a}$ & $\mathrm{NS}$ \\
\hline & Tilapia & $14.97 \pm 0.63 a$ & $14.58 \pm 0.44 \mathrm{a}$ & $15.37 \pm 0.39 a$ & $15.40 \pm 0.13 \mathrm{a}$ & NS \\
\hline & Feed & 28.31 & 28.31 & 28.31 & 28.31 & - \\
\hline \multirow{3}{*}{$\begin{array}{l}\text { Crude } \\
\text { lipid }\end{array}$} & Cowpea & $0.89 \pm 0.10 \mathrm{a}$ & $0.79 \pm 0.02 \mathrm{a}$ & $0.83 \pm 0.04 a$ & $0.90 \pm 0.03 a$ & NS \\
\hline & Tilapia & $4.55 \pm 0.22 \mathrm{a}$ & $4.40 \pm 0.32 \mathrm{a}$ & $4.69 \pm 0.70 \mathrm{a}$ & $4.06 \pm 0.10 \mathrm{a}$ & NS \\
\hline & Feed & 6.88 & 6.88 & 6.88 & 6.88 & - \\
\hline \multirow{3}{*}{$\begin{array}{l}\text { Crude } \\
\text { fiber }\end{array}$} & Cowpea & $5.46 \pm 0.40 \mathrm{a}$ & $5.91 \pm 0.32 \mathrm{a}$ & $5.90 \pm 0.17 \mathrm{a}$ & $6.04 \pm 0.41 \mathrm{a}$ & NS \\
\hline & Tilapia & $1.21 \pm 0.22 \mathrm{a}$ & $1.18 \pm 0.05 \mathrm{a}$ & $1.28 \pm 0.05 \mathrm{a}$ & $1.17 \pm 0.07 \mathrm{a}$ & NS \\
\hline & Feed & 5.20 & 5.20 & 5.20 & 5.20 & - \\
\hline \multirow{3}{*}{ Ash } & Cowpea & $2.33 \pm 0.13 a$ & $2.27 \pm 0.06 \mathrm{a}$ & $2.13 \pm 0.17 \mathrm{a}$ & $2.56 \pm 0.06 b$ & $* *$ \\
\hline & Tilapia & $5.25 \pm 0.52 \mathrm{a}$ & $4.78 \pm 0.56 a$ & $4.72 \pm 0.65 a$ & $5.00 \pm 0.12 \mathrm{a}$ & NS \\
\hline & Feed & 8.79 & 8.79 & 8.79 & 8.79 & - \\
\hline \multirow{3}{*}{$\begin{array}{l}\text { Carbohyd } \\
\text { rate }\end{array}$} & Cowpea & $4.42 \pm 1.06 \mathrm{a}$ & $4.94 \pm 0.88 \mathrm{a}$ & $5.12 \pm 0.52 \mathrm{a}$ & $4.45 \pm 0.50 \mathrm{a}$ & NS \\
\hline & Tilapia & $1.00 \pm 0.83 \mathrm{a}$ & $0.41 \pm 0.43 a$ & $0.90 \pm 0.75 a$ & $0.47 \pm 0.38 \mathrm{a}$ & NS \\
\hline & Feed & 38.58 & 38.58 & 38.58 & 38.58 & - \\
\hline
\end{tabular}

Here, T1, T2, T3 and T4 indicate 2.94, 3.92, 4.90 and $5.88 \mathrm{~kg} \mathrm{~m}^{-3}$ fish stocking densities, respectively. Means $( \pm \mathrm{SD})$ were calculated from three replicates for each treatment. Bars with different letters are significantly different at $\mathrm{P} \leq 0.05$ applying Duncan's Multiple Range Test (DMRT) and similar letters indicate non-significance where $\mathrm{P}>0.05$. ** indicates significance at $\mathrm{P} \leq 0.01$ and NS means non-significance.

The analyzed proximate compositions of cowpea of the present study are similar to the findings of USDA-ARS (2019), where they reported 86, 3.3, 0.3, 3.3 and 9.5\% moisture, crude protein, crude lipid, crude fiber and carbohydrate, respectively in fresh cowpea pod. Moreover, the crude fiber and crude lipid content of cowpea in the present experiment are much higher than those of USDA-ARS (2019) but similar (5.47 to 5.53\%) to the outcomes of Noor $\boldsymbol{e t}$ al. (2014). In case of the tilapia proximate composition, all the components were similar and fish density did not have an effect on the proximate composition except moisture content. Moniruzzaman et al. (2015) reported that the highest density had significantly low amount of lipid and carbohydrate contents compared to the lower fish densities. By contrast, in present aquaponics study, the values were similar which might be due to good water quality, favorable environment and less 
energy expense and homeostasis in all the treatments. Lam et al. (2015) reported 76\% moisture, $16 \%$ protein, $4 \%$ lipid and $4 \%$ ash content in the tilapia in the spinach-tilapia based aquaponics study. Moreover, the protein content in the feed was sufficient for the tilapia growth and welfare of fish as omnivorous fishes require $25-35 \%$ protein in their feed (Somerville et al., 2014).

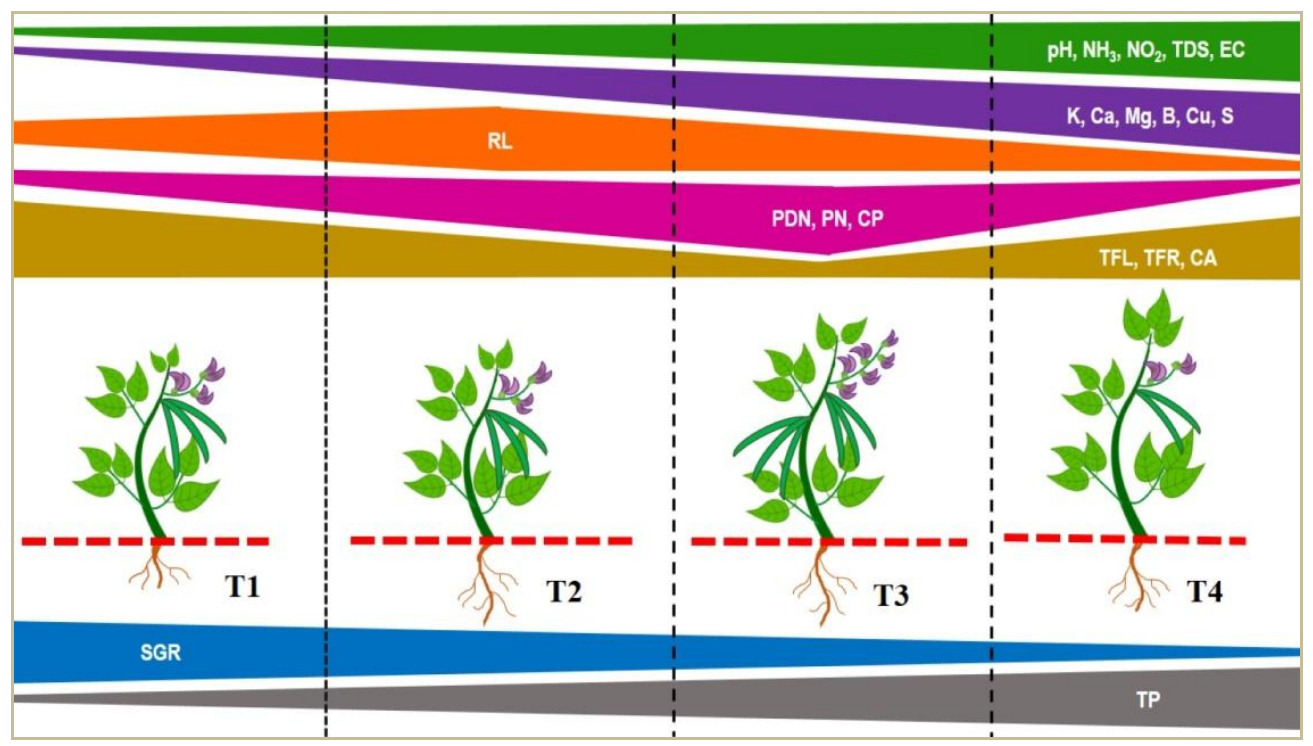

Fig. 4 Conceptual model on the significant effects of four treatments on tank water, cowpea, and the tilapia in aquaponics.

Here, T1: $2.94 \mathrm{~kg} \mathrm{~m}^{-3}$ stocking density of the tilapia; T2: $3.92 \mathrm{~kg} \mathrm{~m}^{-3}$ stocking density of tilapia; T3: $4.90 \mathrm{~kg} \mathrm{~m}^{-3}$ stocking density of tilapia; T4: $5.88 \mathrm{~kg} \mathrm{~m}^{-3}$ stocking density of tilapia; RL: root length; PDN: pod number; PN: picking number; CP: cowpea production; TFL: time for flowering; TFR: time for fruiting, CA: crude ash; SGR: specific growth rate; TP: tilapia production. In the diagram, vertical black lines are used to differentiate the treatments plots; the horizontal red line indicates media base of plants. Moreover, the width of the horizontal and colorful stripes indicate significant differences among the treatments. The highest and the lowest plant heights are shown in the plot of T4 and T1, respectively. Six flowers and cowpeas in T3 indicate the highest cowpea production; two flowers and cowpeas in T4 represent the lowest production of cowpea.

\section{CONCLUSION}

In the present study, cowpea production increased with the increasing fish density from 2.94 to $4.90 \mathrm{~kg} \mathrm{~m}^{-3}$, and then drastically reduced at the highest fish density $(5.88 \mathrm{~kg}$ $\mathrm{m}^{-3}$ ). However, only fish production was increased with the increasing fish density and the highest production was achieved in T4, whereas, SGR of the tilapia reduced with the increasing fish density. Moreover, higher fish densities provided higher quantities of dissolved nutrients for plants but, higher ammonia, nitrite and nitrate escalated the water $\mathrm{pH}$ which reduced the nutrients absorption by the cowpea root system. Such combination 
resulted in late flower and fruit initiation and lowered the yield of cowpea significantly in $\mathrm{T} 4\left(5.88 \mathrm{~kg} \mathrm{~m}^{-3}\right)$. A conceptual diagram on the present experiment is presented in the Fig. (4). The $\mathrm{pH}$ control in this study could have enhanced the cowpea production like fish with the increasing fish densities utilizing the higher amount of nutrients available in the water than that in the lower fish density. The increasing fish stocking density acted positively on the fish and vegetable production up to a certain stage, then cowpea could not withstand higher nutrients in aquaponics water. Therefore, considering the water quality parameters, EC, nutrient concentrations, cowpea and fish production, the fish density of $4.90 \mathrm{~kg} \mathrm{~m}^{-3}$ (T3) could be considered suitable fish stocking density in aquaponics to optimize legume crops.

\section{ACKNOWLEDGEMENTS}

The authors express their gratitude for the financial support by BAS-USDA PALS/2017/282 Project (Bangladesh Academy of Science- United States Department of Agriculture). The authors are also thankful to the staff of 'Fish Nutrition Laboratory', Department of Aquaculture, Bangladesh Agricultural University (BAU), Mymensingh and 'Laboratory of Soil Science Division', Bangladesh Agricultural Research Institute (BARI), Gazipur for their support to carry out proximate composition analysis of fish and cowpea.

\section{CONFLICT OF INTEREST}

The authors declare that there is no conflict of interests regarding the publication of this article.

\section{REFERENCES}

AOAC (2019). Association of Official Analytical Chemist, Official Methods of Analysis Association (21 ${ }^{\text {st }}$ Edition), Arlington, VA.

Ayipio, E.; Wells, D.E.; McQuilling, A. and Wilson, A.E. (2019). Comparisons between aquaponic and conventional hydroponic crop yields: A meta-analysis. Sustainability, 11(22): 1-15. DOI: 10.3390/su11226511.

Badiane, F.A.; Diouf, M. and Diouf, D. (2014). Cowpea. In: Broadening the genetic base of grain legumes. Singh, M.; Bisht, I.S. \& Dutta, M. (Eds.). Springer, New Delhi, 95-114 pp.

Bartelme, R.P.; Oyserman, B.O.; Blom, J.E.; Sepulveda-Villet, O.J. and Newton, R.J. (2018). Stripping away the soil: Plant growth promoting microbiology opportunities in aquaponics. Front. Microbiol. 9: 8. DOI: 10.3389/fmicb. 2018.00008 .

Baxter, I. (2015). Should we treat the income as a combination of individual elements, or should we be deriving novel combined traits? J. Exp. Bot. 66, 2127-2131. http://dx.doi.org/10.1093/jxb/erv040. 
Bittsanszky, A.; Uzinger, N.; Gyulai, G.; Mathis, A.; Junge, R.; Villarroel, M.; Kotzen, B. and Komives, T. (2016). Nutrient supply of plants in aquaponic systems. Ecocycles, 2(2): 17-20. DOI: 10.19040/ecocycles.v2i2.57.

Buzby, K.M. and Lin, L.S. (2014). Scaling aquaponic systems: balancing plant uptake with fish output. Aquac. Eng., 63: 39-44. DOI: 10.1016/j.aquaeng.2014.09.002.

Delaide, B.; Delhayea, G.; Dermienceb, M.; Gottc, J.; Soyeurtd, H. and Jijaklia, M.H. (2017). Plant and fish production performance, nutrient mass balances, energy and water use of the PAFF Box, a small-scale aquaponic system. Aquac. Eng., 78: 130-139. http://dx.doi.org/10.1016/j.aquaeng.2017.06.002.

Delaide, B.; Goddek, S.; Gott, J.; Soyeurt, H. and Jijakli, M.H. (2016). Lettuce (Lactuca sativa L. var. Sucrine) growth performance in complemented aquaponic solution outperforms hydroponics. Water, 8(10): 467. DOI: 10.3390/w8100467.

Dipikaben, M.P.; Varma, L.R. and Kumari, S. (2018). Varietal evaluation of vegetable cowpea [Vigna unguiculata (L.) Walp] with respect to plant growth, flowering and fruiting behavior under north Gujarat condition. Int. J. Curr. Microbiol. App. Sci., 7(7): 3913-3920. https://doi.org/10.20546/ijcmas.2018.707.455.

dos Santos, M.J.P.L. (2016). Smart cities and urban areas- Aquaponics as innovative urban agriculture. Urban For. Urban Green. 20: 402-406. DOI: 10.1016/j.ufug.2016.10.004.

Eck, M.; Körner, O. and Jijakli, M.H. (2019a). Nutrient Cycling in Aquaponics Systems. In: "Aquaponics Food Production Systems". Goddek, S.; Joyce, A.; Kotzen, B. \& Burnell, G. (Eds.), Springer, Cham, Switzerland. pp. 231-246. DOI: 10.1007/978-3-030-15943-6_9.

Eck, M.; Sare, A.R.; Massart, S.; Schmautz, Z.; Junge, R.; Smits, T.H.M. and Jijakli, M.H. (2019b). Exploring bacterial communities in aquaponic systems. Water, 11(2): 260. DOI: 10.3390/w11020260.

Effendi, H.; Wahyuningsih, S. and Wardiatno, Y. (2016). The use of nile tilapia (Oreochromis niloticus) cultivation wastewater for the production of romaine lettuce (Lactuca sativa L. var. longifolia) in water recirculation system. Appl. Water Sci., 7: 3055-3063. DOI: 10.1007/s13201-016-0418-z.

Endut, A.; Lananan, F.; Abdul, Hamid. S.H.; Jusoh, A. and Wan, Nik. W.N. (2016). Balancing of nutrient uptake by water spinach (Ipomoea aquatica) and mustard green (Brassica juncea) with nutrient production by African catfish (Clarias gariepinus) in scaling aquaponic recirculation system. Desalin. Water Treat., 57(60): 29531-29540. https://doi.org/10.1080/19443994.2016.1184593.

Estim, A.; Saufie, S. and Mustafa, S. (2018). Water quality remediation using aquaponics sub-systems as biological and mechanical filters in aquaculture. J. Water Process Eng., 30: 100566. https://doi.org/10.1016/j.jwpe.2018.02.001. 
Goddek, S.; Delaide, B.; Mankasingh, U.; Ragnarsdottir, K.V.; Jijakli, H. and Thorarinsdottir, R. (2015). Challenges of sustainable and commercial aquaponics. Sustainability, 7(4): 4199-4224. DOI: 10.3390/su7044199.

Graber, A. and Junge, R. (2009). Aquaponic systems: nutrient recycling from fish wastewater by vegetable production. Desalination, 246(1-3): 147-156. DOI:10.1016/j.desal.2008.03.048.

Hussain, T.; Verma, A.K.; Tiwari, V.K.; Prakash, C.; Rathore, G.; Shete, A.P. and Nuwansi, K.K.T. (2014). Optimizing koi carp, Cyprinus carpio var. koi (Linnaeus, 1758), stocking density and nutrient recycling with spinach in an aquaponic system. J. World Aquacult. Soc., 45(6): 652-661. DOI: $\underline{10.1111 / j w a s .12159 .}$.

Junge, R.; König, B.; Villarroel, M.; Komives, T. and Jijakli, M.H. (2017). Strategic points in aquaponics. Water, 9(3): 182. DOI: 10.3390/w9030182.

Karikari, B.; Arkorful, E. and Addy, S. (2015). Growth, nodulation and yield response of cowpea to phosphorus fertilizer application in Ghana. J. Agron., 14(4): 234240. DOI: 10.3923/ja.2015.234.240.

Kebede, E. and Bekeko, Z. (2020). Expounding the production and importance of cowpea (Vigna unguiculata (L.) Walp.) in Ethiopia. Cogent Food Agric., 6 (1): 1769805. https://doi.org/10.1080/23311932.2020.1769805.

Knaus, U. and Palm, H.W. (2017). Effects of the fish species choice on vegetables in aquaponics under spring-summer conditions in northern Germany (Mecklenburg Western Pomerania). Aquaculture, 673: https://doi.org/10.1016/j.aquaculture.2017.01.020.

Kyei-Boahen, S.; Savala, C.E.N.; Chikoye, D. and Abaidoo, R. (2017). Growth and yield responses of cowpea to inoculation and phosphorus fertilization in different environments. Front. Plant Sci., 8: 646. DOI: 10.3389/fpls.2017.00646.

Lal, H.; Singh, P.M.; Nath, V. and Singh, R. (2016). An impact assessment of vegetable cowpea, Vigna unguiculata (L.) Walp. Variety "Kashi Kanchan'. Proc. Natl. Acad. Sci., India, Sect. B Biol. Sci., 86(3): 529-536. DOI: 10.1007/s40011-014-0477-6.

Lam, S.S.; Ma, N.L.; Jusoh, A. and Ambak, M.A. (2015). Biological nutrient removal by recirculating aquaponic system: Optimization of the dimension ratio between the hydroponic and rearing tank components. Int. Biodeter. Biodeg., 102: 107115. https://doi.org/10.1016/j.ibiod.2015.03.012.

Lennard, W. and Goddek, S. (2019). Aquaponics: The basics. In: "Aquaponics food production systems: Combined aquaculture and hydroponic production technologies for the future". Goddek, S.; Joyce, A.; Kotzen, B. \& Burnell, G.M. (Eds.), pp. 113-143. DOI: 10.1007/978-3-030-15943-6_5. 
Love, D.C.; Uhl, M.S. and Genello, L. (2015). Energy and water use of a small scale raft aquaponics system in Baltimore, Maryland, United States. Aquac. Eng., 68: 19-27. DOI:10.1016/j.aquaeng.2015.07.003.

Makori, A.J.; Abuom, P.O.; Kapiyo, R.; Anyona, D.N. and Dida, G.O. (2017). Effects of water physico-chemical parameters on tilapia (Oreochromis niloticus) growth in earthen ponds in Teso North Sub-County, Busia County. Fish. Aquat. Sci., 20(1): 30. DOI: 10.1186/s41240-017-0075-7.

Masrufa, S.; Rahman, A.; Hasanuzzaman, M.; Nath, S.C.D.; Ali, M.H.; Anee, T.I. and Hasanuzzaman, M. (2016). Effect of pre-planting hardening of seedlings on growth, dry matter accumulation and tillering of inbreed and hybrid rice. Focus. Sci., 2(2): 1-10. DOI: 10.20286/focsci-020238.

Maucieri, C.; Nicoletto, C.; Os, E.V.; Anseeuw, D.; Havermaet, R.V. and Junge, R. (2019a). Hydroponic technologies. In: "Aquaponics Food Production Systems". Goddek, S.; Joyce, A.; Kotzen, B. \& Burnell, G., (Eds.). Springer, Cham, Switzerland. pp. 77-110. DOI: 10.1007/978-3-030-15943-6-4.

Maucieri, C.; Nicoletto, C.; Zanin, G.; Birolo, M.; Trocino, A.; Sambo, P.; Borin, M. and Xiccato, G. (2019b). Effect of stocking density of fish on water quality and growth performance of European carp and leafy vegetables in a low-tech aquaponic system. Plos One., 14(5): e0217561. https://doi.org/10.1371/ journal.pone.0217561.

Moniruzzaman, M.; Uddin, K.B.; Basak, S.; Mahmud, Y.; Zaher, M. and Bai, S.C. (2015). Effects of stocking density on growth, body composition, yield and economic returns of mono-sex tilapia (Oreochromis niloticus L.) under cage culture system in Kaptai Lake of Bangladesh. J. Aquac. Res. Dev., 6(8): 357-363. DOI: 10.4172/2155-9546.1000357.

Monsees, H.; Kloas, W. and Wuertz, S. (2017). Decoupled systems on trial: Eliminating bottlenecks to improve aquaponic processes. PLoS One., 12(9): e0183056. https://doi.org/10.1371/journal.pone.0183056.

Mustapha, M.K. and Atolagbe, S.D. (2018). Tolerance level of different life stages of Nile tilapia Oreochromis niloticus (Linnaeus, 1758) to low $\mathrm{pH}$ and acidified waters. The J. Basic Appl. Zool., 79: 46. https://doi.org/10.1186/s41936-0180061-3.

Nadia, Z.M.; Roy, P. and Salam, M.A. (2020). Production potential of broccoli (Brassica oleracea var. italica) in hydroponics and tilapia based aquaponics. J. Bangladesh Agril. Univ., 18(3): 768-778. https://doi.org/10.5455/JBAU.106528.

Noor, F.; Hossain, F. and Ara, U. (2014). Screening of French bean (Phaseolus vulgaris L.) genotypes for high yield potential. Bangladesh J. Sci. Ind. Res., 49(4): 227232. DOI: https://doi.org/10.3329/bjsir.v49i4.22625.

Nozzi, V.; Graber, A.; Schmautz, Z.; Mathis, A. and Junge, R. (2018). Nutrient management in aquaponics: Comparison of three approaches for cultivating 
lettuce, mint and mushroom herb. Agronomy., 8(3): 27. DOI: 10.3390/agronomy8030027.

Oladimeji, A.S.; Olufeagba, S.O.; Ayuba, V.O.; Sololmon, S.G. and Okomoda, V.T. (2018). Effects of different growth media on water quality and plant yield in a catfish-pumpkin aquaponics system. J. King Saud Univ. Sci., 32(1): 60-66. DOI: 10.1016/j.jksus.2018.02.001.

Qi, C.; Xie, C.; Tang, R.; Qin, X.; Wang, D. and Li, D. (2016). Effect of stocking density on growth, physiological responses, and body composition of juvenile blunt snout bream, Megalobrama amblycephala. J. World Aquac. Soc., 47(3): 358-368. https://doi.org/10.1111/jwas.12278.

Razaq, M.; Zhang, P.; Shen, H. and Salahuddin. (2017). Influence of nitrogen and phosphorous on the growth and root morphology of Acer mono. PLoS One., 12(2): e0171321. DOI:10.1371/journal. pone.0171321.

Salam, M.A.; Hashem, S.; Asadujjaman, M. and Li, Fusheng. (2014). Nutrient recovery from in fish farming wastewater: An aquaponics system for plant and fish integration. World J. Fish Mar. Sci., 6(4): 355-360. DOI: 10.5829/idosi.wjfms.2014.06.04.8583.

Schmautz, Z.; Graber, A.; Jaenicke, S.; Goesmann, A.; Junge, R. and Smits, T.H. (2017). Microbial diversity in different compartments of an aquaponics system. Arch Microbiol., 199(4): 613-620. DOI: 10.1007/s00203-016-1334-1.

Somerville, C.; Cohen, M.; Pantanella, E.; Stankus, A. and Lovatelli, A. (2014). Small-scale aquaponic food production, Integrated fish and plant farming. FAO Fisheries and Aquaculture Technical Paper No.589. Rome, FAO.

Soti, P.G.; Jayachandran, K.; Koptur, S. and Volin, J.C. (2015). Effect of soil pH on growth, nutrient uptake, and mycorrhizal colonization in exotic invasive Lygodium microphyllum. Plant Ecol., 216(7): 989-998. DOI: 10.1007/s11258015-0484-6.

USDA-ARS (United States Department of Agriculture, Agricultural Research Service) (2019). USDA nutrient database for standard reference, Release 28. USDA-ARS, Beltsville, MD. https://fdc.nal.usda.gov/fdc-app.html\#/fooddetails/168405/nutrients.

Wang, C.Y.; Chang, C.Y.; Chien, Y.H. and Lai, H.T. (2016). The performance of coupling membrane filtration in recirculating aquaponic system for tilapia culture. Int. Biodet. Biodeg., 107: 21-30. DOI:10.1016/j. ibiod.2015.10.016.

Wongkiew, S.; Hu, Z.; Chandran, K.; Lee, J.W. and Khanal, S.K. (2017). Nitrogen transformations in aquaponic systems: a review. Aquac. Eng., 76: 9-19. https://doi.org/10.1016/j.aquaeng.2017.01.004.

Wortman, S.E. (2015). Crop physiological response to nutrient solution electrical conductivity and $\mathrm{pH}$ in an ebb-and-flow hydroponic system. Sci. Hortic., 194: 3442. http://dx.doi.org/10.1016/j.scienta.2015.07.045. 
Yang, T. and Kim, H. (2020). Characterizing nutrient composition and concentration in tomato, basil and lettuce-based aquaponic and hydroponic systems. Water., 12(5): 1259. DOI:10.3390/w12051259.

Yildiz, H.Y.; Robaina, L.; Pirhonen, J.; Mente, E.; Domínguez, D. and Parisi, G. (2017). Fish welfare in aquaponic systems: Its relation to water quality with an emphasis on feed and faeces- a review, Water., 9(1): 13. DOI: 10.3390/w9010013.

Yogev, U.; Barnes, A. and Gross, A. (2016). Nutrients and energy balance analysis for a conceptual model of three loops off grid, aquaponics. Water., 8(12): 589. DOI:10.3390/w8120589. 